\title{
Study of Serum Creatinine Level in Hypothyroidism
}

\author{
Neha Jaiswal ${ }^{1}$, Dileep S Nirwan ${ }^{2}$
}

\begin{abstract}
Background: Hypothyroidism is associated with many biochemical abnormalities. Many studies were done abroad regarding serum creatinine levels in hypothyroid patients. We designed this study in our population to evaluate serum creatinine levels in hypothyroid patients.

Objective: To assess serum creatinine levels in hypothyroid patients and to find out the relationship of creatinine levels with the severity of hypothyroidism.

Materials and methods: This is a retrospective cross-sectional study that aims to evaluate the serum creatinine levels of hypothyroid patients and to find out the relationship between hypercreatininemia and severity of hypothyroidism. The study was done in the Department of Biochemistry, PDU Medical College and attached group of hospitals, Churu, western Rajasthan. Results were compared with that of age- and sex-matched healthy euthyroid controls. Statistical analyses were done by using the SPSS version 16.0. ANOVA and unpaired $t$ tests were done to see the significance among the groups and between groups, respectively. The Pearson's correlation coefficient test was done to see the correlation of serum creatinine with the severity of hypothyroidism.

Results: Mean serum creatinine levels in cases were $0.922 \pm 0.16$ compared to $0.798 \pm 0.098 \mathrm{mg} / \mathrm{dL}$ in controls.

Conclusion: Mean serum creatinine levels were found significantly higher in hypothyroid patients compared to controls. These findings suggest that hypercreatininemia is associated with hypothyroidism. Therefore, patients presenting with this biochemical abnormality are recommended to be investigated to explore hypothyroidism.

Keywords: Autoimmune diseases, Hypercreatininemia, Hypothyroidism, Thyroid hormones.

Journal of Mahatma Gandhi University of Medical Sciences \& Technology (2018): 10.5005/.jp-journals-10057-0083
\end{abstract}

\section{INTRODUCTION}

Hypothyroidism is a clinical syndrome resulting from a deficiency of thyroid hormones, which, in turn, results in a generalized slowing down of metabolic processes. ${ }^{1}$ It is a common metabolic disorder in general population. ${ }^{2}$ The thyroid dysfunction increases with age, especially in women. ${ }^{3}$

The prevalence of primary hypothyroidism is 1:100 but it may be 5:100 if patients with subclinical hypothyroidism [normal T4, raised thyroid stimulating hormone (TSH)] are included (0.5-2.0\% in female and $0.2 \%$ in male). ${ }^{4}$ Iodine deficiency is the most common cause of hypothyroidism worldwide. ${ }^{5}$ In most parts of the world, iodine is a scarce component of soil, and hence it is little in food. ${ }^{6}$ In area of iodine sufficiency, autoimmune disease (Hashimoto's thyroiditis) and iatrogenic causes are the most common causes of hypothyroidism. ${ }^{5}$

Hypothyroidism is associated with many biochemical abnormalities including increased serum creatinine levels. The serum creatinine concentration increases in hypothyroid patients due to reduction of glomerular filtration. ${ }^{7}$ The serum creatinine level may also be increased due to hypothyroid myopathy. In hypothyroidism, associated autoimmune diseases may also play a role in modifying the underlying renal problem.

\section{Materials and Methods}

\section{Place of Study}

The study was conducted in collaboration of Department of Medicine and Department of Biochemistry at PDU Medical College and attached group of hospitals, Churu, between January 2019 and July 2019.

\section{Ethical Committee}

Approval was obtained from the Ethical Committee of PDU Medical College, Churu, Rajasthan.

\footnotetext{
1,2Department of Biochemistry, PDU Medical College and Hospital, Churu, Rajasthan, India

Corresponding Author: Dileep S Nirwan, Department of Biochemistry, PDU Medical College and Hospital, Churu, Rajasthan, India, Phone: +91 9929843965, e-mail: dsnktr1983@gmail.com

How to cite this article: Jaiswal N, Nirwan DS. Study of Serum Creatinine Level in Hypothyroidism. J Mahatma Gandhi Univ Med Sci Tech 2018;3(3):79-81.

Source of support: Department of Medicine, PDU Medical College, Churu Conflict of interest: None
}

\section{Study Design}

It was a prospective cross-sectional study.

\section{Sample Size}

We included total 100 subjects out of which 50 subjects were diagnosed cases of hypothyroidism and 50 served as control.

\section{Study Population}

People attending the outpatient Department of Medicine and Biochemistry laboratory of PDU Medical College and attached group hospitals.

\section{Inclusion Criteria}

Patients which were newly detected cases of hypothyroidism in age group of 21-45 years. Both male and female patients were included in the study.

\section{Exclusion Criteria}

Persons on thyroxine treatment, pregnancy, lactating mothers, renal disease, liver disease, cardiovascular disease, hypertension,

() The Author(s). 2018 Open Access This article is distributed under the terms of the Creative Commons Attribution 4.0 International License (https://creativecommons. org/licenses/by-nc/4.0/), which permits unrestricted use, distribution, and non-commercial reproduction in any medium, provided you give appropriate credit to the original author(s) and the source, provide a link to the Creative Commons license, and indicate if changes were made. The Creative Commons Public Domain Dedication waiver (http://creativecommons.org/publicdomain/zero/1.0/) applies to the data made available in this article, unless otherwise stated. 
diabetes mellitus, gout, muscular disorders, malignancy, smoking, alcoholism, patients on drugs (hypolipidemic drugs, antihypertensives, steroids, probenecid, allopurinol, etc.), and H/o chemotherapy or radiotherapy for malignancy were excluded.

\section{Control Group}

Both male and female persons in the age group of 21-45 years having normal thyroid profile (euthyroid) acted as control.

\section{Estimation of Creatinine}

\section{Method}

Modified Jaffe's method (alkaline picrate method).

\section{Results}

The creatinine levels in hypothyroid patients and euthyroid controls were analyzed using the unpaired Student's $t$ test, and correlation between the thyroid profile ( $\mathrm{T} 3, \mathrm{~T} 4, \mathrm{TSH})$ and the serum creatinine value in hypothyroid patients was analyzed using the Pearson's correlation coefficient test (Table 1). By means of Statistical Package for Social Sciences (SPSS) software version 16, the analysis of statistics was performed. The statistical significance was drawn at $p$ value $<0.05$ (Table 2).

According to Table 3, when comparing the serum creatinine level between cases and controls it was found that there was a significant increase in the creatinine value in the study group than in the control group.

According to Table 4, when correlating between the thyroid profile (T3, T4, TSH) and serum creatinine in hypothyroid patients, the correlation between T4 and creatinine, correlation between T3 and creatinine, and correlation between TSH and creatinine were all weak and not statistically significant.

\section{Discussion}

The present study aimed to evaluate the effect of hypothyroidism on serum creatinine concentration and to compare it with euthyroid subjects and also to study the correlation.

Table 1: Age distribution among cases and control groups

\begin{tabular}{lllc}
\hline Age (in years) & Case & Control & Total \\
\hline $21-30$ & 15 & 30 & 45 \\
$31-40$ & 25 & 12 & 37 \\
$41-45$ & 10 & 08 & 18 \\
Total & 50 & 50 & 100 \\
Mean & 34.14 & 29.92 & \\
Standard deviation & 6.95 & 7.33 & \\
$p$ value & 0.00396 & Significant & \\
\hline
\end{tabular}

Table 2: Sex distribution among cases and control groups

\begin{tabular}{lccc}
\hline Gender & Case & Control & Total \\
\hline Male & 5 & 4 & 9 \\
Female & 45 & 46 & 91 \\
Total & 50 & 50 & 100 \\
\hline
\end{tabular}

Persons with age group 21-45 years were included in this study. Mean ages of this study group and control group were 34.14 years and 29.92 years, respectively. Most of the people in this study belong to age group of 31-40 years and control group belong to age group of 21-30 years, which is similar to a study done by Chaudhury et al., ${ }^{8}$ the most common age group 30-39 years, the mean age of hypothyroid and controls were nearly same. However, hypothyroidism was found more common in the 25-35 years age group, similar to the study done by Rashead et al., ${ }^{9}$ with highest percentage of people were in the age group 26-45 years.

Among cases, 5 were males and 45 were females and in healthy controls 4 were males and 46 were females. The percentage rate of females was more than the percentage rate of males, similar to the study by Chaudhury et al., who recorded hypothyroidism that was more frequent in females. Qahtan et al. and Tejomani et al. ${ }^{10}$ also observed that prevalence of hypothyroidism was higher among females.

The mean serum creatinine values of the study and control groups were 0.922 and $0.798 \mathrm{mg} / \mathrm{dL}$, respectively. When comparing the mean serum creatinine values between study and control groups, it was high in the study group than in the control group and the difference was statistically highly significant. This is due to the effect of hypothyroidism on renal physiology, which leads to decrease in renal plasma flow and impaired glomerular filtration and impaired creatinine excretion, thereby increase in serum creatinine levels.

Jayagopal et al. ${ }^{11}$ studied the effects of the hypothyroid state on changes in serum creatinine in 17 patients with hypothyroidism. All patients were newly diagnosed. The hypothyroid patients had a mean serum creatinine level of $1.02 \mathrm{mg} / \mathrm{dL}$. It had been confirmed that the rise in creatinine levels in hypothyroid patients did not relate to abnormalities in other renal functions or creatine kinase levels suggesting that neither hypothyroid myopathy nor intrinsic renal disease contributed to the changes seen in creatinine levels. Similar results were found by Tayal et al. ${ }^{12}$ and Sinisa et al. ${ }^{13}$ In this study, serum creatinine had positive correlation with T3 (0.0621) and TSH (0.1631), and negative correlation with T4 (-0.0645). But all were weak and statistically not significant.

In Tayal et al., there was significant negative correlation between serum creatinine and serum T3 and T4 levels and a significant positive correlation of serum creatinine with TSH levels. In Tejomani et al., there was a significant negative correlation between $\mathrm{T} 3$ and creatinine and a significant positive correlation between creatinine and TSH. In Chaudhary et al., TSH had a positive significant correlation with serum creatinine. Mamatha et al. ${ }^{14}$ showed a significant positive correlation between TSH and serum creatinine levels.

In Jia et al., ${ }^{15}$ TSH showed a weak negative correlation with creatinine, fT3, and $\mathrm{fT} 4$ and also showed a significant negative correlation with creatinine. In Kaur et al., ${ }^{16} \mathrm{TSH}$ showed a significant positive correlation with serum creatinine levels whereas fT4 and fT3 did not show any significant correlation with creatinine. Therefore, these studies are showing mixed observations.

\section{Conclusion}

The present study showed that there is increased creatinine levels in the study group as compared to the control group. These changes in

Table 3: Mean value of creatinine among cases and control groups

\begin{tabular}{lllllll}
\hline & \multicolumn{3}{c}{ Case } & & \multicolumn{3}{c}{ Control } & \\
\cline { 2 - 3 } Substance & Mean & $S D$ & & Mean & $S D$ & $p$ value \\
\hline Creatinine $(\mathrm{mg} / \mathrm{dL})$ & 0.922 & 0.16 & & 0.798 & 0.098 & $<0.00001$ significant \\
\hline
\end{tabular}


Table 4: Correlation between thyroid profile and serum creatinine levels in hypothyroid patients

\begin{tabular}{lcl}
\hline & $\begin{array}{l}\text { Serum creatinine } \\
(\mathrm{mg} / \mathrm{dL}) r \text { value }\end{array}$ & $p$ value \\
\hline Thyroid hormones $(\mathrm{ng} / \mathrm{mL})$ & 0.0621 & 0.668 (not significant) \\
$\mathrm{T} 4(\mu \mathrm{g} / \mathrm{dL})$ & -0.0645 & 0.658 (not significant) \\
$\mathrm{TSH}(\mu \mathrm{lU} / \mathrm{mL})$ & 0.1631 & 0.258 (not significant) \\
\hline
\end{tabular}

the biochemical values are because of the renal dysfunction leading to decrease in the e-GFR level. Thus, these findings are helpful in understanding the interaction between the thyroid gland and the kidney, showing the detrimental effect of the hypothyroid state on renal functioning. This renal impairment is often overlooked but is readily reversible by prompt treatment leading to normalization of biochemical markers.

\section{References}

1. Greenspan FS. The thyroid gland. In: Greenspan FS, Gardner DG, ed. Basic \& Clinical Endocrinology, 7th ed. New York: The McGraw-Hill Companies; 2004. pp. 215-294.

2. Liberopoulos EN, Elisaf MS. Dyslipidemia in patients with thyroid disorders. Hormones (Athens) 2002;1(4):218-223. DOI: 10.14310/ horm.2002.1170.

3. Duntas LH. Thyroid disease and lipids. Thyroid 2002;12(4):287-293. DOI: 10.1089/10507250252949405.

4. Walker BR, Toft AD. Endocrine disease. In: Haslett C, Chilvers ER, Boon $N A$, et al., ed. Davidson's principles and practice of medicine, 19th ed. London: Churchill Livingstone; 2002. pp. 683-746.

5. Jameson JL, Weetman AP. Disorders of the thyroid gland. In: Braunwald E, Fauci AS, Kasper DL, et al., ed. Harrison's principles of internal medicine, 15th ed., New York: McGraw-Hill; 2001. pp. 2060-2084.

6. Granner DK. Thyroid hormones. In: Murray RK, Granner DK, Mayes PA, et al., ed. Harper's biochemistry, 25th ed., Stamford: Appleton \& Lange; 2000. pp. 561-566.

7. Karanikas G, Schutz M, Szabo M, et al. Isotopic renal function studies in severe hypothyroidism and after thyroid hormone replacement therapy. Am J Nephrol 2004;24(1):41-45. DOI: 10.1159/000075628.

8. Chaudhury HS, Raihan KK, Uddin MN, et al. Renal function impairment in hypothyroidism. Bangladesh J Med Biochem 2013;6(1):19-25. DOI: 10.3329/bjmb.v6i1.13283.

9. Rashead QA, Hamid DM. The effect of thyroid hormone on some biochemical factors of kidney. Int J Adv Res 2015;3(7):290-297.

10. Tejomani M, Meera KS, Vasudha KC. Relevance of creatine kinase activity and serum creatinine levels in hypothyroidism. Int J Recent Trends Sci Technol 2013;8(3):263-269.

11. Jayagopal V, Keevil BG, Atkin SL, et al. Paradoxical changes in cystatin $\mathrm{C}$ and serum creatinine in patients with hypo and hyperthyroidism. Clin Chem 2003;49(4):680-681. DOI: 10.1373/49.4.680.

12. Tayal D, Chawla R, Arora S, et al. Dynamic changes in biochemical markers of renal function with thyroid status - a study in Indian population. Int J Med Update 2009;4(2):36-41.

13. Sinisa S, Daniela PG, Todor G, et al. Impact of thyroid dysfunction on serum cystatin $C$, serum creatinine and glomerular filtration rate. Maced J Med Sci 2011;4(1):25-30.

14. Mamatha BV, Rakshitha MN, Kashinath RT, et al. Evaluation of serum urea and creatinine levels in subclinical hypothyroidism - a case control study. Med Innovatica 2016;5(2):3-6.

15. Jia D, Liang LB, Tang GH, et al. The association between serum uric acid and creatinine in patients with hypothyroidism. Sichuan Da Xue Xue Bao Yi Xue Ban 2015;46(5):747-749.

16. Kaur V, Singh K, Verma M. Changes in biochemical markers of renal function in subclinical and overt hypothyroidism. Int J Bioassays 2015;4(04):3799-3802. 